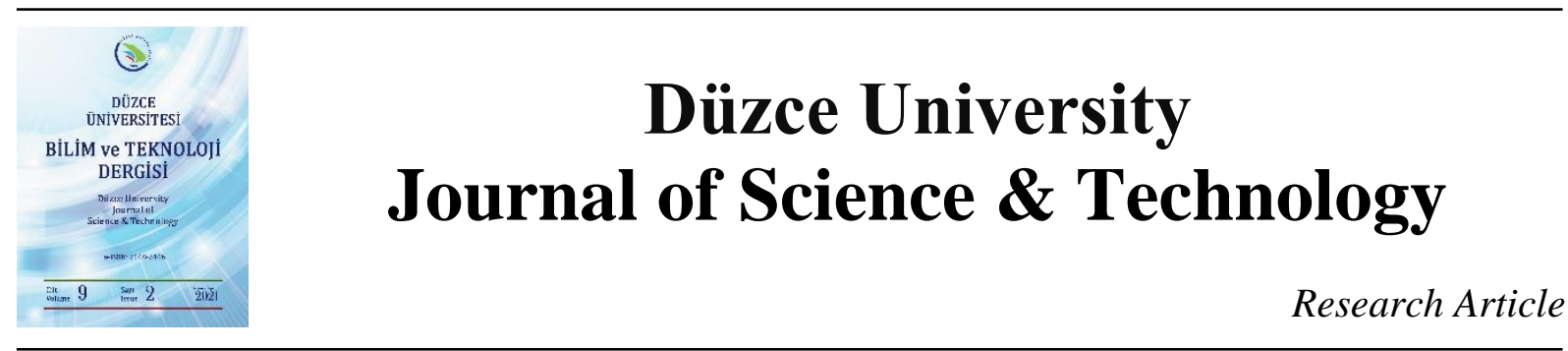

\section{Hydrophobic Modification of Glass Surface by Using Sol-Gel Synthesized Glass Powder as A Surface Roughness Promoter}

\author{
Yiğitalp OKUMUŞ ${ }^{a, *}$, (D) Göktuğ GÜNKAYA ${ }^{\text {b }}$ \\ ${ }^{a}$ Department of Materials Science and Engineering, Graduate School of Sciences, Eskişehir Technical \\ University, Eskişehir, TURKEY \\ ${ }^{b}$ Department of Glass, Faculty of Fine Arts, Anadolu University, Eskişehir, TURKEY \\ * Corresponding author's e-mail address: ggunkaya@anadolu.edu.tr
}

DOI: 10.29130/dubited.656089

\begin{abstract}
In this study, it was aimed to form a hierarchical surface by using glass powders in the coating solution which was applied to glass surfaces for reducing the surface energy. Glass powders (GP) were synthesized by sol gel method at room temperature in the presence of ammonium hydroxide as an alkali catalyst and ethanol water mixture as solvent. Glass powders were used as additives in the chemical modification material to form rough surfaces for obtaining hydrophobic property on the borosilicate substrates. Two solutions were prepared by using different silane types and three different amounts of glass powders were added to each. Substrates were coated with the prepared coating suspension. The coated samples were heat treated for curing of silane matrix at $110^{\circ} \mathrm{C}$ for an hour and then washed. The morphology and the size of the particles were visualized by scanning electron microscopy. Water contact angle measurements were carried out to determine the contact angle values and consequent hydrophobic features. 3 different powder ratios were used. Water contact angle values increased by the increasing powder ratio. Water contact angle values were reached to $115^{\circ}$ from $20^{\circ}$.
\end{abstract}

Keywords: Coatings on glass, Contact angle, Hydrophobic surfaces, Sol-Gel glasses

\section{Yüzey Pürüzlülüğünü Arttırıcı Eleman Olarak Sol-Jel ile Sentezlenmiș Cam Tozu Kullanımıyla Cam Yüzeyinin Hidrofobik Modifikasyonu}

\begin{abstract}
ÖZET
$\mathrm{Bu}$ çalışmada, yüzey enerjisini azaltmak için cam yüzeylere uygulanan kaplama çözeltisinde cam tozları kullanılarak hiyerarşik bir yüzey oluşturulması amaçlanmıştır. Cam tozları, katalizör amonyum hidroksit ve çözücü etanol su karışımı kullanılarak oda sıcaklığında sol jel yöntemiyle sentezlenmiştir. Borosilikat altlık üzerinde hidrofobik özellik elde etmek amacıyla, pürüzlü yüzeyler oluşturmak üzere kimyasal modifikasyon malzemesinde katkı maddesi olarak cam tozlar kullanılmıştır. Farklı silan tipleri ile iki çözelti hazırlanmıştır ve her birine üç farklı miktarda cam tozu eklenmiştir. Altlıklar hazırlanan kaplama süspansiyonu ile kaplanmıştır. Kaplanan numuneler silan matrisinin $110^{\circ} \mathrm{C}$ 'de bir saat süreyle kürlenmesi için ısıl işleme tabi tutulup yıkanmıştır. Morfoloji ve taneciklerin boyutu, taramalı elektron mikroskobu ile incelenmiştir. Temas açısı değerlerinin ve sonuçta ortaya çıkan hidrofobik özelliklerin belirlenmesi için statik temas açısı ölçümleri yapılmıştır. 3 farklı toz oranı kullanılmıştır. Su temas açısı değerleri artan oranla artmıştır. Su temas açısı değerlerinde $20^{\circ}$ 'den $115^{\circ}$ ye artış gözlenmiştir.
\end{abstract}

Anahtar Kelimeler: Cam yüzeyini kaplama, Temas açısı, Hidrofobik yüzeyler, Sol-jel camları

Received: 06/12/2020, Revised: 05/02/2021, Accepted: 07/02/2021 


\section{INTRODUCTION}

Surfaces always behave differently from solid materials, because they show sudden changes in regions near the phase boundaries. Surface atoms and molecules are not stable because they are not completely in a single phase and contain unsaturated bonds. This causes an energy surplus on the surface and this energy is called surface free energy [1-4]. When the water droplet does not prefer to contact the surface energetically it forms a spherical shape by inserting air into the region in contact with solid to reduce the liquid solid interface and increase the liquid gas and solid gas interface [5-7].

Surfaces can be changed to hydrophobic by chemical and physical modifications The contact angle values can be increased by applying chemical modification to reduce the surface free energy and physical modification to create roughness on the surface less than the capillary radius of the water (c in schematic figure) (3).

Glass powders can be used for many applications, such as composite reinforcement material, sinter addition, coating and paint addition [8,-9]. It is known that glass powders produced by the sol-gel method using metal alkoxides are purer and require lower temperatures than those produced by conventional melting processes [10-13]. Homogeneous glassy inorganic materials with desired properties, such as hardness, optical permeability and porosity can be obtained at temperatures close to room temperature by the sol-gel method [14-16].

Alkylthiols and silane agents are used to reduce surface energy (Physical bonds, adsorption, coating). Khorasani et al. [17] obtained WCA $\sim 175^{\circ}$ value with porosity and chain arrangement in PDMS (polydimethylsiloxane) material using CO2-pulsed laser. Teshima [18] produced PET substrates by oxygen plasma etching and provided tetramethylsilane (TMS) with CVD to their surface. In the work done by Hikita et al. [19], sol-gel film was prepared by using colloidal silica particles + fluoroalkyl silane (FAS). Superhydrophobicity was achieved by hydrolysis and condensation of the alkoxysilane composition.

In this study, it is aimed to use sol-gel synthesized glass powder in the hydrophobic modification of glass surface as a hierarchical surface agent.

\section{EXPERIMENTAL}

\section{A. MATERIALS}

Tetraethoxysilane (99\%) was purchased from Abcr chemicals, Germany. [3-(2,3-Epoxypropoxy)propyl] trimethoxysilane (EPMS), boric acid and ammonium hydroxide solution (25\%) were purchased from Merck, Germany. Potassium hydroxide and glacial acedic acid were purchased from VWR Chemicals, USA. Ethanol was purchased from JT Baker Chemicals, Acids and Solvents. Deionized water having 18.2 M $\Omega$ resistance was obtained by using Millipore milli-Q Direct 8 water purification system. 3-Aminopropyl triethoxysilane (APTES, 99\%) was purchased from ACROS Organics, USA. Substrates were cut from commercially available borosilicate glass into $20 \mathrm{X} 20 \mathrm{~mm}^{2}$ squares.

\section{B. SOL GEL-SYNTHESIS OF BOROSILICATE GLASS POWDER}

Two-step sol-gel process was used to obtain glass powders (Fig. 1). At the first step of the process, boric acid was used as boron source, potassium hydroxide as an alkaline source (monovalent metal hydroxide such as $\mathrm{NaOH}$ or $\mathrm{KOH}$ ) and tetraethoxysilane as silicon source. They were mixed in water-ethanol mixture in the presence of glacial acetic acid as solubility promoter (Table 1). At the second step of the process, a basic catalyst solution (ammonium hydroxide) was added drop by drop in the mixture to adjust the final $\mathrm{pH}$ value to 6-7. After gelation has occurred, a drying process has been performed in a 
drying oven at $100^{\circ} \mathrm{C}$ to finalize the synthesis and obtain the powders. Agglomerated particles were crushed gently in an agate mortar.

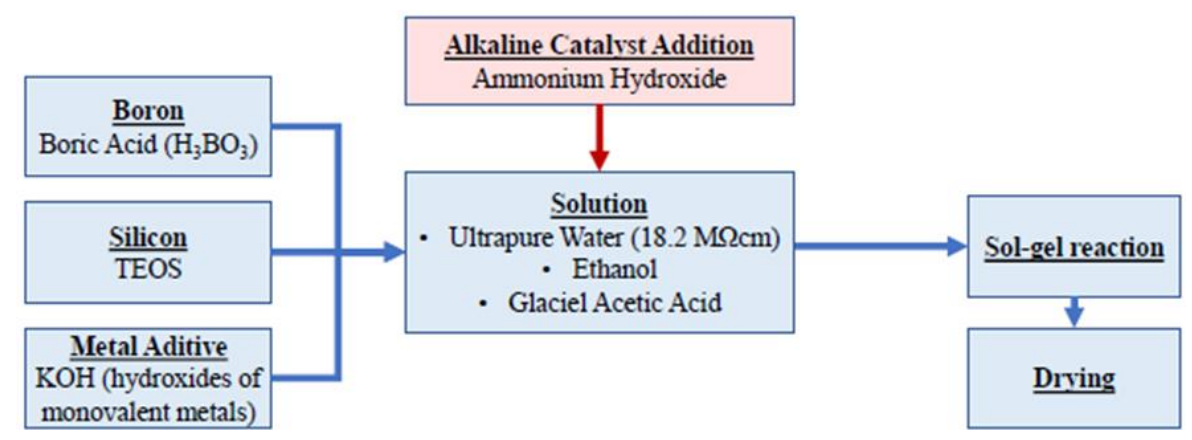

Figure 1. Borosilicate glass powder synthesis by sol-gel method

Table 1. Glass and solution compositions

\begin{tabular}{|c|c|c|c|c|c|c|c|}
\hline \multicolumn{3}{|c|}{$\begin{array}{l}\text { Glass Composition } \\
\text { (Molar Ratio) }\end{array}$} & \multicolumn{5}{|c|}{$\begin{array}{c}\text { Solution Composition } \\
\text { (Molar Ratio) }\end{array}$} \\
\hline TEOS & $\begin{array}{l}\text { Boric } \\
\text { Acid }\end{array}$ & $\begin{array}{l}\text { Potassium } \\
\text { Hydroxide }\end{array}$ & TEOS & Ethanol & Water & $\begin{array}{l}\text { Ammonium } \\
\text { Hydroxide }\end{array}$ & $\begin{array}{l}\text { Acetic } \\
\text { Acid }\end{array}$ \\
\hline 20 & 40 & 1 & 0.83 & 33.9 & 44.6 & 0.102 & 0.25 \\
\hline
\end{tabular}

Initial $\mathrm{pH}$ of solution was controlled to increase the soluble amounts of precursors by adding acetic acid. Catalyst types, amounts, solution $\mathrm{pH}$ and reaction temperature were optimized for the particle size of the final products.

\section{COATING PROCEDURE}

Many scientific and technical studies require clean surfaces. Otherwise adhesion problems may occur partially or completely [1]. Washing and drying steps were applied to glass surfaces for a perfect interface and adhesion between the coating and the substrates. Washing process was carried out respectively in ultrasonic bath in five chambers with different liquid contents. There were basic solution containing $3-10 \%$ sodium hydroxide in the first chamber (pH: 9), deionized water in the second, acidic solution containing $2-4 \%$ phosphoric acid in the third (pH: 1) and deionized water in the fourth and fifth ones. Substrates were soaked in each chamber for 5 minutes (Fig. 2). After the washing process, all substrates were dried at $100^{\circ} \mathrm{C}$ for $10-15$ minutes in a drying oven.

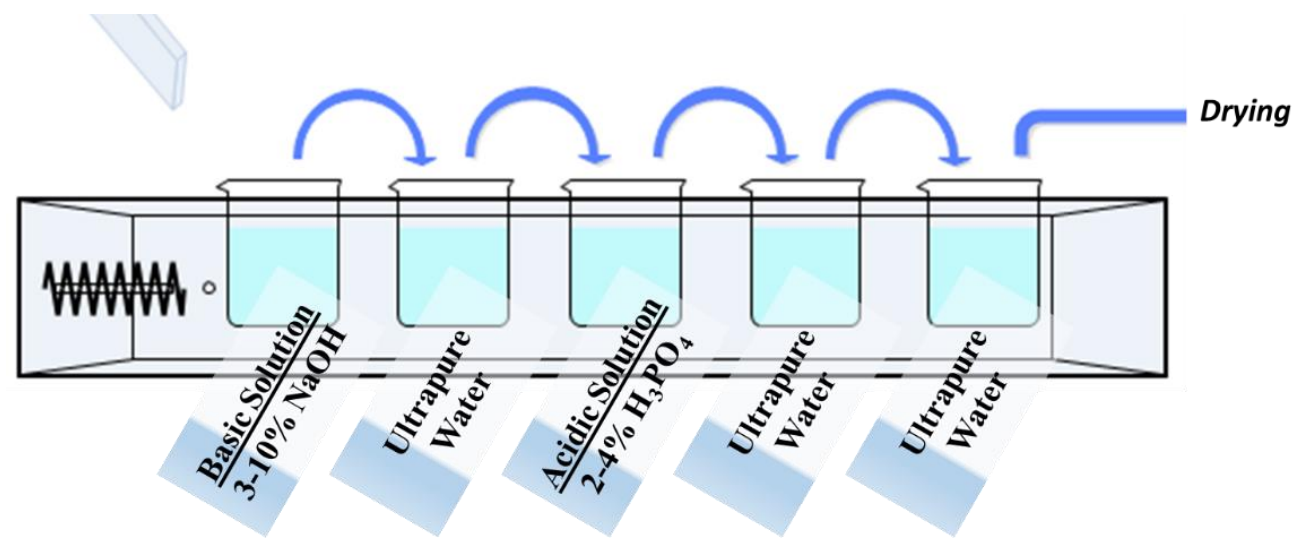

Figure 2. Cleaning of the substrate surfaces 
Different coating suspensions with glass powders of $5 \mathrm{~g} / \mathrm{L}, 10 \mathrm{~g} / \mathrm{L}$ and $15 \mathrm{~g} / \mathrm{L}$ were prepared. Glass powders were dispersed in ethyl alcohol-deionized water solution (10:1 in volume) with a sonication time of 3 minutes. After dispersion, v. 10\% APTES and v. 10\% EPMS were added separately in each and stirred for two hours. Coating processes were performed by using Proxxon Airbrush AB100 with a nozzle diameter of $0.2 \mathrm{~mm}$ and sample-nozzle distance of $150 \mathrm{~mm}$ (Fig. 3). Coated samples were heated to $110^{\circ} \mathrm{C}$ and dwelled for an hour for curing reaction of silanes [20].

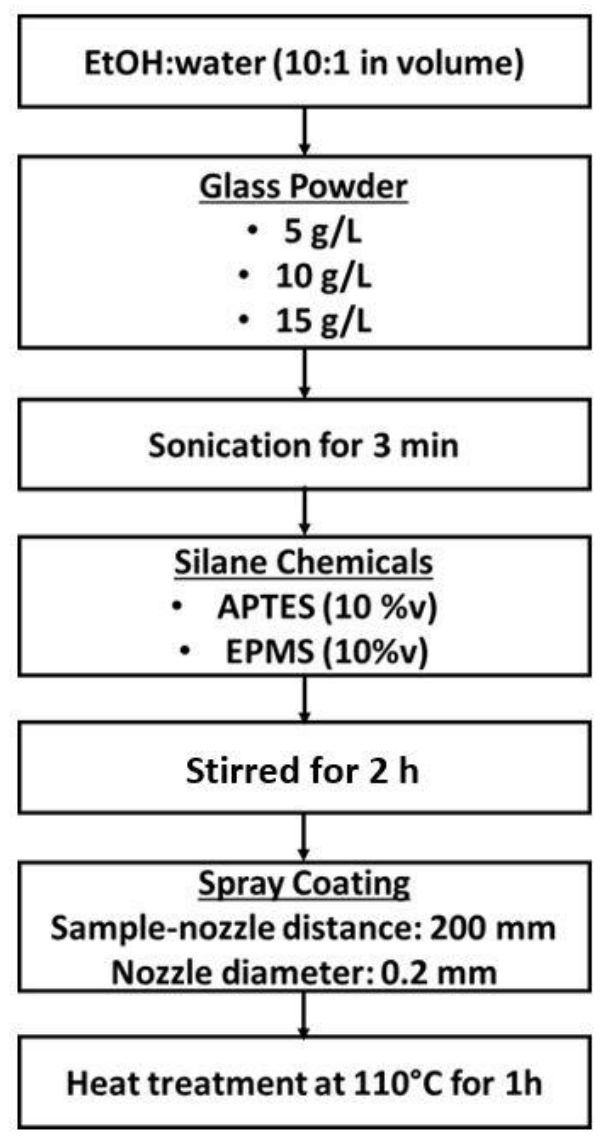

Figure 3. Flowchart of suspension preparation and coating

\section{CHARACTERIZATION}

Structural characterization of sol-gel synthesized powders has been made by using Rigaku, MiniFlex600, Rigaku ${ }^{\mathrm{TM}}$ Co., Ltd., Tokyo, Japan X-ray diffractometer in the $2 \theta$ range between $10^{\circ}$ and $70^{\circ}$ at a scan speed of $1 \%$ min with $\mathrm{Cu} \mathrm{K \alpha}$ radiation.

Morphological characterization and the particle size analysis of obtained powders and coated samples were carried out using ZEISS Supra 50 VP scanning electron microscopy (SEM) with $20 \mathrm{kV}$ accelerating voltage and secondary electron imaging after gold sputtering. Particle size of powder was measured by using Malvern Nano ZS in suspension before coating process.

The effect of the coating to hydrophobic character was investigated by measuring the water contact angle values using Biolin Scientific Attension contact angle instrument. Contact angles were measured by ultrapure water-based sessile drop method. Ultrapure water with a surface tension value of 73.5 $\mathrm{mNm}^{-1}$ and a resistivity of $18.2 \mathrm{~m} \Omega$ was used. The tabulated contact angle data were derived from average value of at least five measurements performed at room temperature in different points of the sample surface. 


\section{RESULTS AND DISCUSSION}

\section{A. MORPHOLOGICAL AND STRUCTURAL CHARACTERIZATION OF BOROSILICATE GLASS POWDER}

Particle size is a crucial property for hierarchical surface elements in hydrophobic modification. The scale of the surface roughness must not allow water droplets to intervene and spread. The particle size of the sol-gel synthesized glass powders was investigated by scanning electron microscopy. Figure 4a shows the secondary electron image of glass powder. The image implicates the particle size of the powders was $50 \mathrm{~nm}$ on average. Detailed information about the powder synthesis study can be found in the other publication of the study team [21]. Glass samples show neither sharp peak nor crystalline pattern (Fig. 4b). The broad peak centered at $23^{\circ}$ clearly indicated that the glass particles are fully amorphous. The particle size distribution of sol-gel synthesized glass powders in suspension was determined bimodal size distribution as $50 \mathrm{~nm}$ and $250 \mathrm{~nm}$ (Fig. 5). $50 \mathrm{~nm}$ size distribution peak describes primary particles and $250 \mathrm{~nm}$ size distribution peak remarks agglomerates.

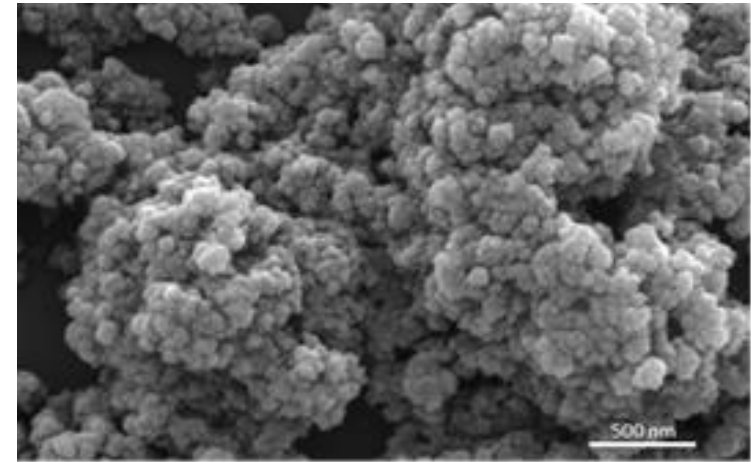

(a)

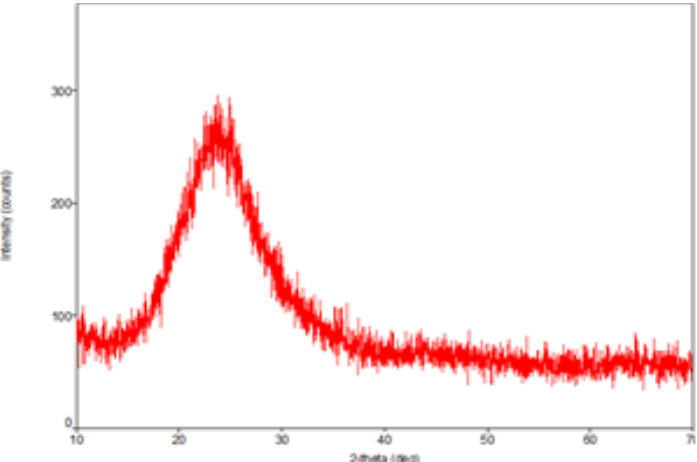

(b)

Figure 4. SEM image (a) and XRD analysis (b) of sol-gel synthesized glass powder

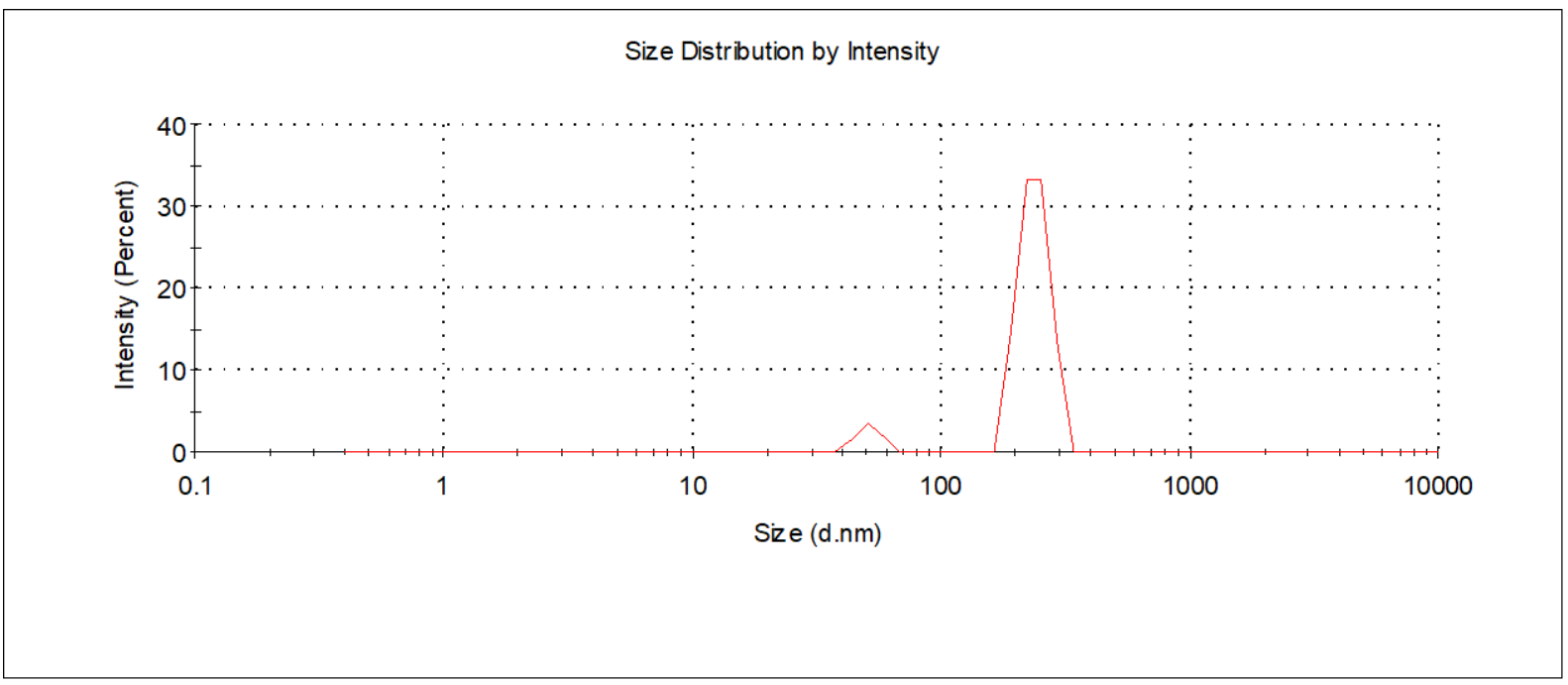

Figure 5. Particle size distribution of sol-gel synthesized glass powder

\section{B. MORPHOLOGICAL CHARACTERIZATION OF COATED SAMPLES}

It can be seen in Figure 6 that the EPMS modified samples had no particulate surfaces but instead outspread EPMS and sponge-like morphology. The rough surface could not be achieved when using 
EPMS. Conversely APTES modified samples had particles on coating surfaces. When powder ratio reached to $15 \mathrm{~g} / \mathrm{L}$, uniformity of the surface had been deteriorated.

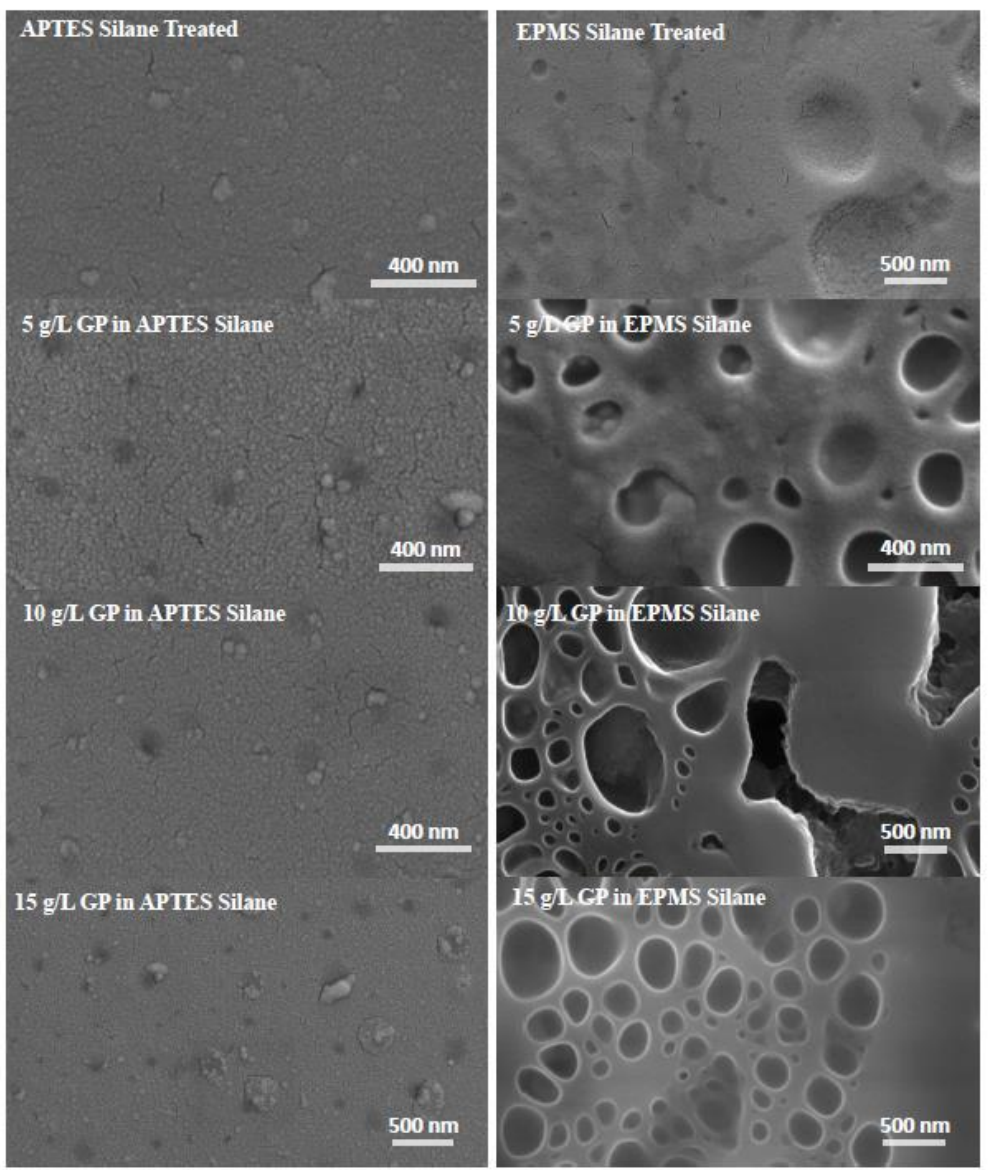

Figure 6. SEM of coated samples

\section{WATER CONTACT ANGLE ANALYSIS OF COATED SAMPLES}

Water contact angle measurements were performed to investigate the effect of silane type and glass powder amount on hydrophobic modification. Figure 7 and 8 shows verification of contact angle results of each samples. Untreated borosilicate glass substrate had an average contact angle value of $20^{\circ}$.

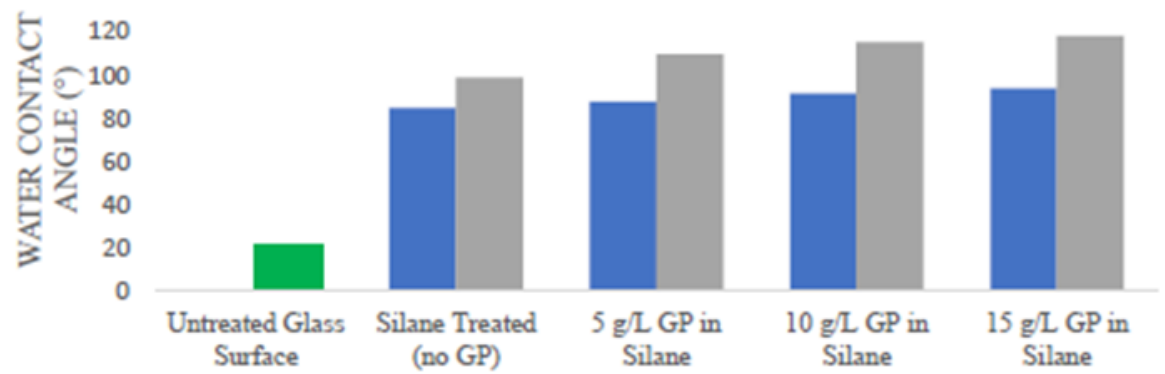

[3-(2,3-Epoxypropoxy)-propyl] trimethoxysilane (EPMS) $\square$ 3-Aminopropyl triethoxysilane (APTES)

Figure 7. Verification of contact angle values 


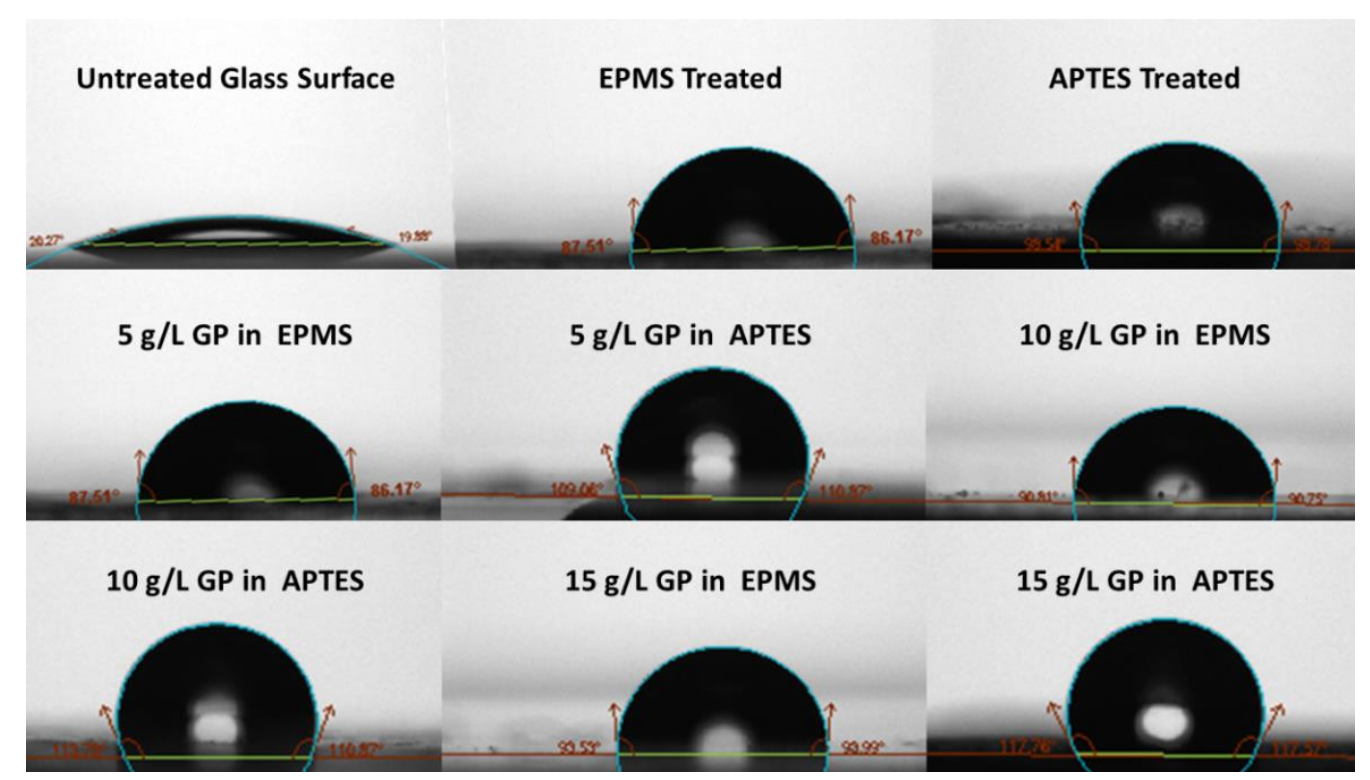

Figure 8. Images of water droplets on coated samples

In consistence with morphological analysis that showed no particulate structure on surfaces of EPMS modified samples, when EPMS used, glass powder addition did not have a significant effect on hydrophobicity. Whereas APTES was used in surface modification, increasing powder addition caused an increase in contact angle values (Table 2).

Table 2. Contact Angle values of modified samples $\left({ }^{\circ}\right)$

\begin{tabular}{|c|c|c|c|c|c|}
\hline & $\begin{array}{c}\text { Untreated } \\
\text { Glass } \\
\text { Surface }\end{array}$ & $\begin{array}{l}\text { Silane Treated } \\
\text { (No GP) }\end{array}$ & $\begin{array}{l}5 \mathrm{~g} / \mathrm{L} \mathrm{GP} \text { in } \\
\text { silane }\end{array}$ & $\begin{array}{c}10 \mathrm{~g} / \mathrm{L} \mathrm{GP} \\
\text { in } \\
\text { silane }\end{array}$ & $\begin{array}{c}15 \mathrm{~g} / \mathrm{L} \text { GP } \\
\text { in } \\
\text { silane }\end{array}$ \\
\hline $\begin{array}{l}\text { 3-(2,3-Epoxypropoxy)- } \\
\text { propyl]-trimethoxysilane }\end{array}$ & \multirow{2}{*}{$20.93 \pm 0.40$} & $84.50 \pm 0.70$ & $87.50 \pm 0.70$ & $91.35 \pm 0.50$ & $93.88 \pm 1.50$ \\
\hline $\begin{array}{c}\text { 3-Aminopropyl } \\
\text { triethoxysilane(APTES) }\end{array}$ & & $98.80 \pm 0.60$ & $109.66 \pm 0.60$ & $\begin{array}{c}115.07 \\
\pm 0.50\end{array}$ & $\begin{array}{l}117.93 \\
\pm 2.00\end{array}$ \\
\hline
\end{tabular}

\section{CONCLUSIONS}

According to this ongoing study it was concluded that GP addition increased the contact angles by roughening the surface. 3 different powder ratios were used. When the powder ratio got greater than 15 $\mathrm{g} / \mathrm{L}$, sedimentations and agglomerations were occurred and caused congestions in spray nozzle. That situation defined the upper limit as $15 \mathrm{~g} / \mathrm{L}$. Due to investigation of the effect of used powder ratios, contact angles increased by the increasing ratio. Nevertheless uniformity of coating was decreased in 15 $\mathrm{g} / \mathrm{L}$ samples and that induced a rise in error deviation. Therefore optimum powder amount was specified as $10 \mathrm{~g} / \mathrm{L}$. As a result of comparison of two silane types, APTES showed higher contact angle values as $115^{\circ}$. Simple and versatile spray coating method with sol-gel processing was used to prepare hydrophic coating on glass.

ACKNOWLEDGEMENT: This study was supported by scientific research projects of Anadolu University (Project number of 1704E092). 


\section{REFERENCES}

[1] H. K. Pulker, "Cleaning of substrates" in Coatings on Glass, 1st ed., New York, USA: Elsevier, 1987, ch. 4, pp. 60-72.

[2] N. J. Shirtcliffe, G. Mchale, S. Atherton, M.I. Newton, "An introduction to superhydrophobicity," Advances in Colloid and Interface Science, vol. 161, pp. 124-138, 2010.

[3] Z. Guo, W. Liu, B.L. Su, "Superhydrophobic surfaces: From natural to biomimetic to functional," Journal of Colloid and Interface Science, vol. 353, pp. 335-355, 2011.

[4] J.L. Zhang, J.A. Li, Y.C. Han, "Superhydrophobic PTFE surfaces by extension," Macromol Rapid Communications, vol. 25, pp. 1105-1108, 2004.

[5] M. T. Khorasani, H. Mirzadeh, Z.Kermani, "Wettability of porous polymethylsiloxane surface: Morphology study,” Applied Surface Science, vol. 242, pp. 339-345, 2005.

[6] M. Ma, R.M. Hill, J.L. Lowery, S.V. Fridrikh, G.C. Rutledge, "Electrospun poly(styreneblockdimethylsiloxane) block copolymer fibers exhibiting superhydrophobicity," Langmuir, vol. 21, pp. 5549-5554, 2005.

[7] N. Zhao, Q.D. Xie, L.H. Weng, S.Q. Wang, X.Y. Zhang, J. Xu, "Superhydrophobic surface from vapor-induced phase separation of copolymer micellar solution," Macromolecules, vol. 38, pp. 8996-8999, 2005

[8] J. Y. Dinga, D. E. Day, "Preparation of silica glass microspheres by sol-gel processing," Journal of Materials Research, vol. 6, pp. 168-174, 1991.

[9] I. S. Kim, R. Kim, H. Son, "Nano glass powder for sintering additive and method for fabricating the same," U.S. Patent 0138215 A1, Jun. 7, 2012.

[10] C. J. Brinker, S. P. Mukherjee, "Conversion of monolithic gels to glasses in a multicomponent silicate glass system,” Journal of Materials Science, vol. 16, pp. 1980-1988, 1981.

[11] L.C. Klein, T.A. Gallo, G. J. Garvey, "Densification of monolithic gels below $1000^{\circ}$ C," Journal of Non-Crystalline Solids, vol. 63, pp. 23-33, 1984.

[12] C. J. Brinker, K. D. Keefer, D.W. Schaefer, C.S. Ashley, "Sol-gel transition in simple silicates," Journal of Non-Crystalline Solids, vol. 48, pp. 47-64, 1982.

[13] S. Sakka, "Gel method for making glass," in Treatise on Materials Science and Technology: Glass III, New York, USA: Academic Press, 1982, ch. 3 pp. 129-167.

[14] C. J. Brinker, G.W. Scherer, "Introduction" in Sol-gel Science-The Physics and Chemistry of Sol-Gel Processing, 1st ed., New York, USA: Academic Press, 1990, ch. 1, pp. 1-17.

[15] W. Li, D. P. Fries, A. Malik, "Sol-gel stationary phases for capillary electro chromatography," Journal of Chromatography A, vol. 1044, pp. 23-52, 2004.

[16] T. L. Metroke, R. L. Parkhill, E.T. Knobbe, "Passivation of metal alloys using sol-gel derived materials - a review," Progress in Organic Coatings, vol. 41, pp. 233-238, 2001.

[17] M. T. Khorasani, H. Mirzadeh, Z. Kermani, "Wettability of porous polydimethyl siloxane surface: morphology study," Applied Surface Science, vol. 242, no. 3, pp. 339-345, 2005. 
[18] K. Teshima, H. Sugimura, Y. Inoue, O. Takai, A. Takano, "Transparent ultra water-repellent poly(ethylene terephthalate) substrates fabricated by oxygen plasma treatment and subsequent hydrophobic coating," Applied Surface Science, vol. 244, no. 1, pp. 619-622, 2005.

[19] M. Hikita, K. Tanaka, T. Nakamura, T. Kajiyama, A. Takahara, "Super liquid- repellent surfaces prepared by colloidal silica nanoparticles covered with fluoroalkyl groups," Langmuir, vol. 21, no. 16, pp. 7299-3702, 2005.

[20] M. Qin, S. Hou, L. Wang, X. Feng, R. Wang, Y. Yang, C. Wang, L. You, B. Shao, M. Qiao, "Two methods for glass surface modification and their application in protein immobilization," Colloids and Surfaces B: Biointerfaces, vol. 60, pp. 243-249, 2007.

[21] Y. Okumus, G. Gunkaya, "A facile approach for the effect of solution, catalyst and temperature on the synthesis of glass powder by the sol-gel method," Romanian Journal of Materials, vol. 49, no. 4, pp. 455-460, 2019. 